\title{
SOSIALISASI PENDAMPING PENGGUNAAN SMARTPHONE TERHADAP ANAK
}

\author{
Enjang Pera Irawan \\ Program Studi Ilmu Komunikasi, Fakultas Ilmu Komunikasi, Universitas Mercu Buana \\ Jl. Meruya Selatan No 1 Meruya Selatan, Kembangan Jakarta Barat- Indonesia \\ E-mail : enjang.irawan@mercubuana.ac.id
}

\begin{abstract}
ABSTRAK
Mengingat perkembangan teknologi komunikasi dan informasi semakin pesat ditandai dengan maraknya penggunaan smartphone, hal ini tentu memiliki berbagai dampak baik positif maupun negatif. Untuk itu, program sosialisasi penggunaan smartphone ini sangat tepat untuk dilakukan dengan tujuan membantu meminimalisir dampak negatif dari penggunaan smartphone, dan menggali potensi positif dari penggunaan smartphone. Program sosialisasi ini dilaksanakan untuk mengedukasi anak-anak dilingkungan Rt 001 Rw 01 Kelurahan Meruya Selatan, Kecamatan Kembangan Jakarta Barat sejumlah 30 peserta. Metode sosialisasi dengan ceramah, diskusi dan tanya jawab, serta simulasi. Hasil kegiatan ini diharapkan para orang tua menyadari akan pentingnya cara mendampingi dan mengawasi anak dalam menggunakan smartphone dengan tepat. Selain itu, peserta dapat memberikan edukasi kepada dan mengontrol penggunaan smartphone. Melalui sosialisasi para peserta dapat menglaksanakan proses pendapingan penggunaan smartphone pada anak dengan baik dan benar.
\end{abstract}

Kata Kunci: sosialisasi; menggunaan smartphone; pendampingan anak.

\section{ABSTRACT}

Along with the rapid development of information and communications technology marked by the rise of smartphone usage, this certainly has both positive and negative impacts. For this reason, the smartphone usage socialization program is very appropriate to be carried out to minimize negative impacts and optimize positive impacts of smartphone usage. This socialization program was carried out to educate children in the RT (Neighborhood Association) 001, RW (Community Association) 01, South Meruya Village, Kembangan Subdistrict, West Jakarta with 30 participants. The methods of socialization used were lectures, questions and answers, demonstrations and discussions. From this activity, it was expected that parents would realize the importance of how to assist and supervise children in using smartphones properly. In addition, participants could provide education and control smartphone usage. Through the socialization, participants could give an assistance of smartphone usage to children properly and correctly.

Keyword: socialization, smartphone, children assistance.

\section{PENDAHULUAN}

Merujuk pada data emarketer, pada tahun 2018 bahwa Indonesia akan memiliki lebih dari 100 juta pengguna smartphone aktif. Kondisi ini menjadikan Indonesia sebagai negara peringkat 4 dunia pengguna smartphone terbanyak [1]. Tidak dapat dipungkiri bahwa saat ini tumbuh kembang anak dipengaruhi oleh berbagai faktor eksternal, khususnya teknologi. Keberadaan teknologi ini tidak hanya berdampak positif, namun juga memberikan dampak negatif. Tentu hal inilah yang perlu dipikirkan solusinya.

Berdasarkan survey APJII (Asosiasi Pengguna Jasa InternetIndonesia) pada tahun 2017 diketahui bahwa pertumbuhan pengguna internet di Indonesia semakin meningkat (APJII, 2017). Pada tahun 2017, telah terjadi peningkatan pengguna internet mencapai 143,26 juta jiwa. Terjadi peningkatan sebesar 16,68\% pada rentang usia anak-anak sampai remaja (13-18 tahun). Pada rentang usia tersebut mayoritas menggunakan gadget untuk mengakses internet. Smartphone, tablet, komputer, kamera, laptop merupakan jenis-jenis gadget yang banyak digunakan. Adanya fitur yang lengkap ini, membuat gadget digunakan juga oleh pegawai kantoran, orang tua, hingga anak-anak. Gadget dinilai dapat memudahkan kita melakukan berbagai kegiatan kapan pun dan dimana pun [2]. 
Teknologi yang saat ini hampir dapat diakses oleh semua orang dari berbagai kalangan usia yaitu smartphone. Keberadaan dan dampak smartphone tidak saja memapar orang-orang dewasa, tetapi anak belia pun tidak lepas dari paparan smartphone. Berbagai penelitian menunjukan bahwa smartphone dapat membuat anak menjadi terganggu saat belajar. Lebih jauh lagi anak menjadi kesulitan beronsentrasi, bahkan anak akan tidak peduli dengan lingkungan sekitar. Anak lebih sering berimajinasi mengenai tokoh game yang sering dimainkan pada smartphone nya.

Selain sumber informasi dan pengetahuan, smartphone juga memiliki berbagai dampak negative. Secara spesifik hasil penelitian menunjukan bahwa banyak sekali pengaruh negatif dari penggunaan smartphone secara tidak proporsional. Disisi lain dampak positif penggunaan gadget pada anak diantaranya: (1) Dapat meningkatkan daya imajinasi dan berfikir; (2) Melatih kecerdasan dalam aspek menulis, angka, serta gambar; (3) Rasa percaya diri anak akan meningkat ketika mereka berhasil menyelesaikan suatu permainan; serta (4) Menumbuhkan rasa ingin tahu, mengembangkan kemampuan dalam membaca, matematika, dan pemecahan masalah. Sedangkan dampak negatif penggunaan gadget terhadap anak diantaranya: (1) anak memiliki kecenderungan mudah menyerah; (2) anak memiliki kemampuan motorik yang kurang berkembang; (3) emosi anak menjadi meledak-ledak; (4) keterampilan sosial anak menjadi berkurang; dan (5) anak berpotensi terpapar konten berbau pornografi atau kriminalitas [3].

Hasil penelitian World Health Organization (WHO) menunjukan bahwa Kecenderungan anak dalam menggunakan smatphone dan tabletnya untuk bermain game lebih tinggi dibandingkan untuk aplikasi edukasi, hal ini tentu menjadi masalah yang memprihatinkan. Lebih lanjut WHO memaparkan bahwa kecanduan game merupakan penyakit gangguan mental. Bermain game disebut sebagai gangguan mental hanya apabila permainan tersebut menggangu atau merusak kehidupan pribadi, keluarga, sosial, pekerjaan, dan pendidikan [4].

Dari sekian banyak dampak negatif dari smartphone ini tentu kita sebagai orang tua dituntut untuk lebih peka dan peduli terhadap berbagai aktivitas anak, khususnya terkait penggunaan smartphone oleh anak. Orang tua harus mampu menciptakan komunikasi efektif dengan cara menjadi teman yang menyenangkan bagi anak, menjadi pendengar bagi anakanaknya, tidak hanya bicara saja, mendengar kritik dan saran dari anak-anak mengenal kelemahan orang tua. Orangtua harus bisa menyampaikan pesannya tanpa emosi, dan tindakan-tindakan persuasif lainnya yang dapat dimengerti anak. Hal ini penting untuk dilakukan agar anak dapat terbuka dan menjadikan orang tua sebagai tempat curahan hati (curhat), sehingga berbagai tindakan anak dapat terkontrol dengan baik. Namun sayangnya tidak sedikit orang tua yang belum tahu atau mungkin belum sensitif terhadap isu-isu seperti ini, hal ini dikarenakan berbagai faktor seperti minimnya pengetahuan, minimnya waktu berinteraksi dengan anak, kesibukan kerja, dan lain sebagainya.

Untuk dapat memberikan pemahaman kepada masyarakat, maka Pemerintah dan berbagai stakeholder termasuk institusi Pendidikan perlu meningkatkan intensitas sosialisasi dan pembinaan pada masyarakat terkait berbagai permasalahan sosial yang ada di masyarakat. Narwako dan Suyanto (2007) menjelaskan bahwa Lewat proses sosialisasi, individu-individu masyarakat belajar mengetahui dan memahami tingkah laku pekerti apakah yang harus dilakukan, dan tingkah laku pekerti apakah yang harus tidak dilakukan [5].

Untuk itu penulis menyadari bahwa penting untuk dilaksanakan kegiatan "Sosialisasi Pendampingan Penggunaan Smartphone Terhadap Anak”. Sebagai staf pengajar di Bidang Studi 
Public Relations Fakultas Ilmu Komunikasi Universitas Mercu Buana Jakarta, penulis menilai sosialisasi ini merupakan program pengabdian kepada masyarakat yang penting untuk dilaksanakan.

\section{METODE PELAKSANAAN}

Dari sekian banyak dampak negatif dari smartphone ini tentu kita sebagai orang tua dituntut untuk lebih peka dan peduli terhadap berbagai aktivitas anak, khususnya terkait penggunaan smartphone oleh anak. Orang tua harus mampu menciptakan komunikasi efektif dengan cara menjadi teman yang menyenangkan bagi anak, menjadi pendengar untuk anak, belajar menerima saran dan kritik dari anak. Orangtua harus mampu mengemas dan menyampaikan pesannya dengan tenang tanpa emosi, dan tindakan-tindakan persuasif lainnya yang dapat dimengerti anak. Hal ini penting untuk dilakukan agar anak dapat terbuka dan menjadikan orang tua sebagai tempat curahan hati (curhat), sehingga berbagai tindakan anak dapat terkontrol dengan baik.

Sebagai upaya mengatasi masalah tersebut maka diperlukan sebuah sosialisasi secara komprehensif terkait bagaimana melatih ibu-ibu untuk dapat melakukan pendampingan penggunaan smartphone terhadap anak. Adapun metode yang akan digunakan diantaranya yaitu: 1) Metode ceramah yaitu materi disampaikan dengan paparan terkait fenomena dan berbagai analisa ilmiah terkait permasalahan yang ada serta solusi yang ditawarkan. 2) Metode diskusi dan tanya jawab yaitu pembicara memberikan kesempatan kepada peserta untuk berdiskusi atau menyampaikan pedapat dan pertanyaan. 3) Metode demonstrasi yaitu pembicara mencoba memandu para peserta untuk mempraktekan teknik-teknik yang telah disampaikan terkait bagaimana mendampingi anak ketika menggunakan smartphone.

Khalayak yang menjadi sasaran dalam program pengabdian masyarakat dalam bentuk "Sosialisasi Pendampingan Penggunaan Smartphone Terhadap Anak" ini yaitu Ibu rumah tangga, diutamakan ibu-ibu PKK di lingkungan Universitas Mercu Buana, tepatnya di Rt 001 Rw 01 Kelurahan Meruya Selatan, Kecamatan Kembangan Jakarta Barat sejumlah 31 peserta. Kemudian dilakukan evaluasi serta penilaian dengan mengajukan daftar pertanyaan kepada peserta secara terbuka mengenai pemahaman mereka terhadap materi yang disosialisasikan, kemudian beberapa perwakilan peserta diminta menyimpulkan hasil dari proses sosialisasi tersebut secara terbuka. Selain itu, kami juga melihat partisipasi publik pada saat kegiatan sosialisasi berjalan.

Berikut ini merupakan kerangka kerja program pengabdian masyarakat yang penulis lakukan, seperti pada gambar 1 berikut ini: 


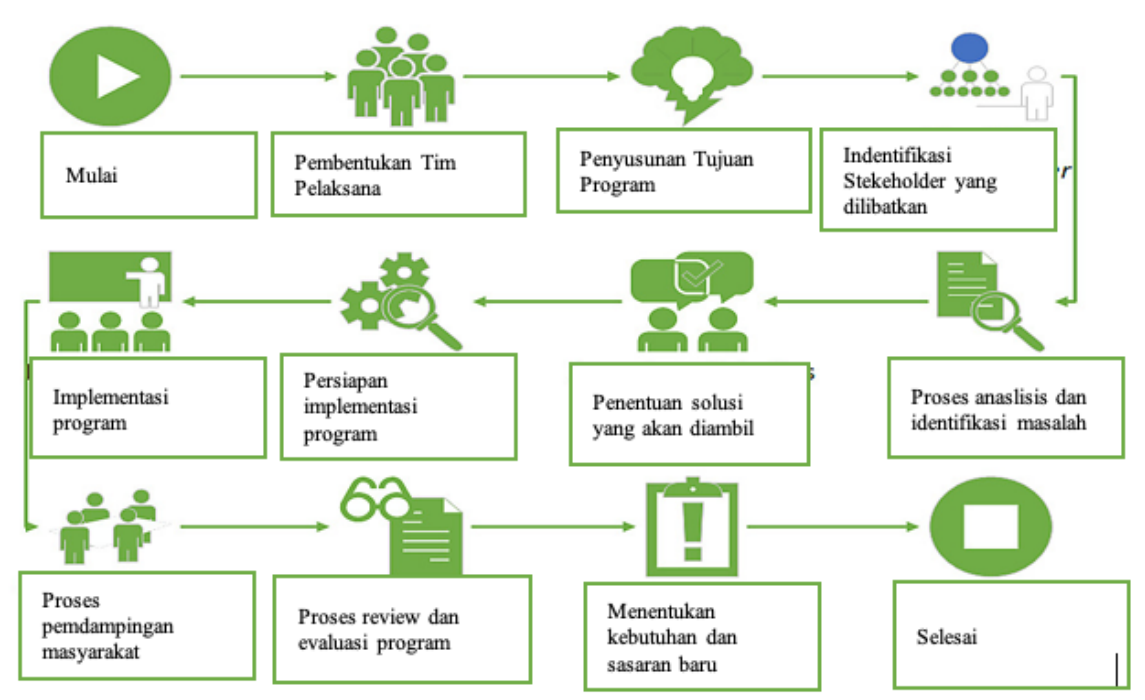

Gambar 1. Kerangka Kerja Kegiatan Program Pengabdian

\section{HASIL}

Kegiatan sosialisasi ini diawali sambutan oleh Ibu Novi Erlita, S.Sos, MA sebagai perwakilan dari Bidang Studi Public Relations Fikom UMB. Setelah sambutan dan pembukaan dilakukan, berikutnya sosialisasi pun dimulai dengan penyampaian materi oleh Ibu Yuniani, S.Sos, M.Ikom serta dimoderatori bapak Enjang Pera Irawan, S.Sos, M.I.Kom. Kegiatan Sosialisasi dilaksanakan pada Selasa, 26 April 2016 dari pukul 12.15 sd 14.25 wib di Universitas Mercu Buana. Khalayak yang menjadi sasaran dalam kegiatan pengabdian "Sosialisasi Pendampingan Penggunaan Smartphone Terhadap Anak ini adalah Ibu rumah tangga, diutamakan ibu-ibu PKK di lingkungan Universitas Mercu Buana, tepatnya di Rt 001 dan Rt 003 Rw 001 Kelurahan Meruya Selatan, Kecamatan Kembangan Jakarta Barat, sejumlah 30 orang peserta. Program sosialisasi ini dilaksanakan di lingkungan Kampus Universitas Mercu BuanaBerikut, seperti pada gambar 2 berikut ini:

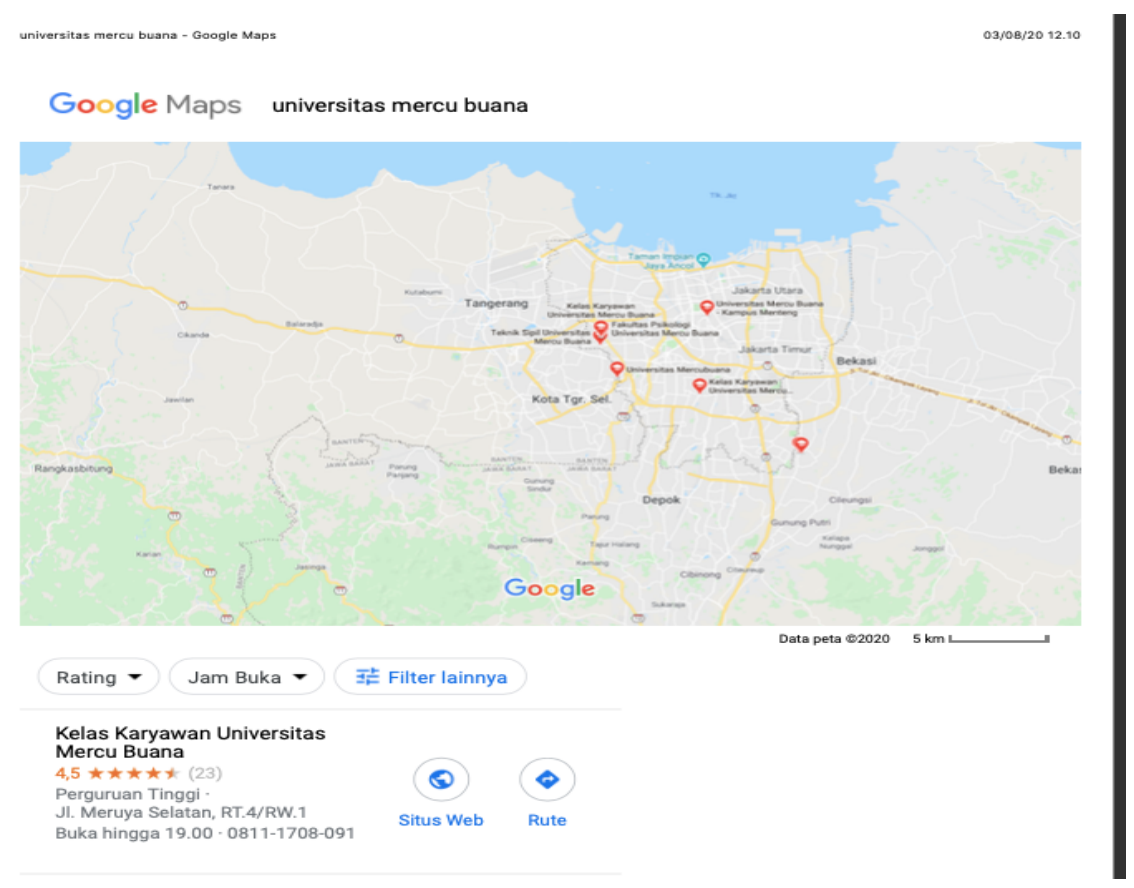

Gambar 2. Lokasi Kegiatan Program Pengabdian 
Pemilihan kampus Universitas Mercu Buana sebagai lokasi program pengabdian masyarakat ini karena di lokasi tersebut terdapat berbagai fasilitas pendukung seperti laptop, LCD, Wireless Presenter, Sound System, dan Kamera dokumentasi. Dengan didukung oleh fasilitas tersebut, hal ini dapat membantu peserta dalam mengkap materi yang diberikan oleh narasumber. Dengan demikian, pelaksanaan program pengabdian masyarakat dalam bentuk sosialisasi ini dapat berjalan dengan baik, selain itu memudahkan peserta sosialisai menerima dan memahami materi yang diberikan oleh Narasumber.

Materi yang disampaikan dalam Sosialisasi "Pendampingan Penggunaan Smartphone Terhadap Anak" ini terkait informasi mengenai pentingnya pengawasan terhadap anak dalam penggunaan smartphone, bahaya penggunaan smartphone tanpa pendampingan, tips-tips bagaimana membangun keterbukaan anak agar mau didampingi. Hal ini sebagaimana pada gambar 3 berikut ini:

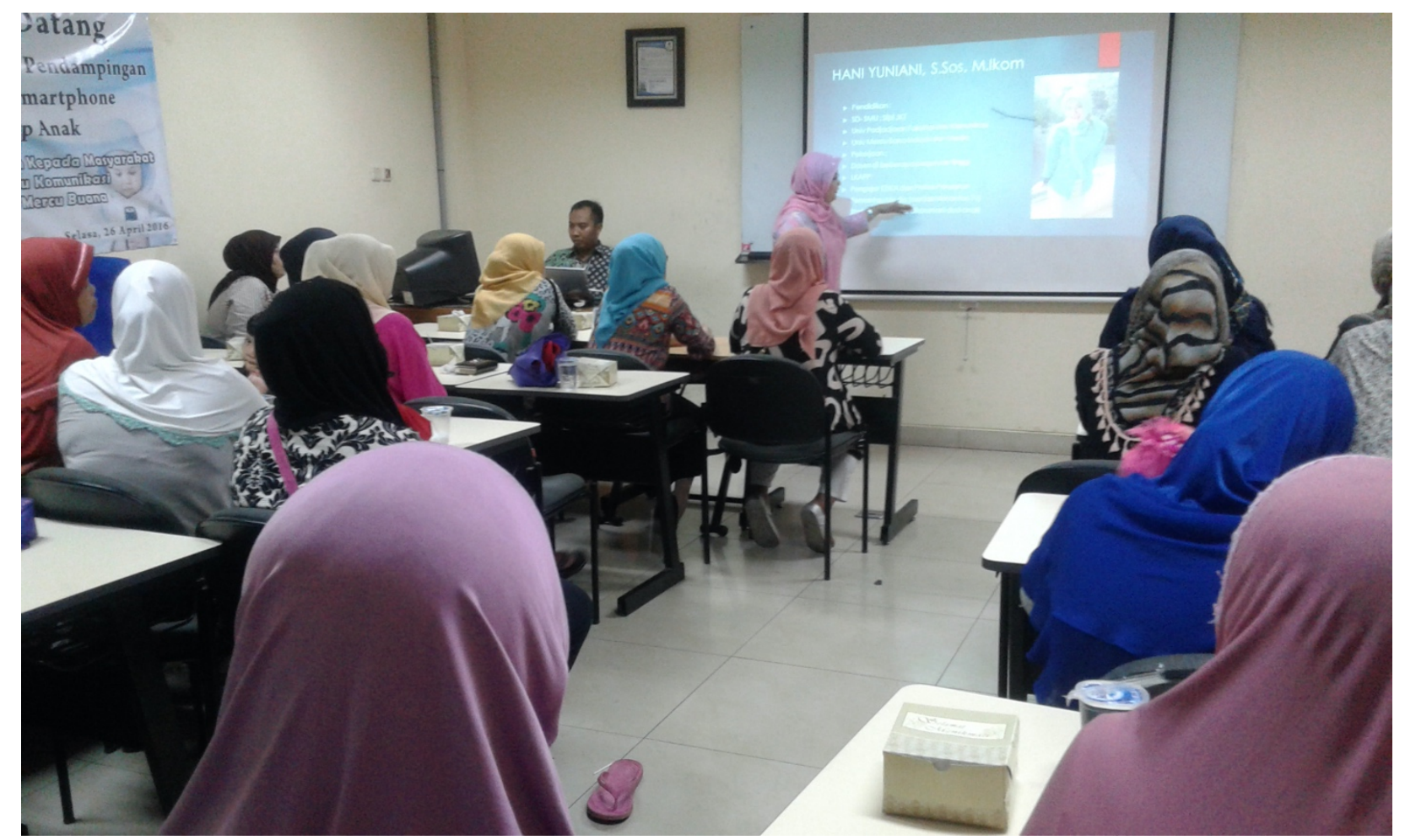

Gambar 3. Pemberian Materi Sosialisasi

Pada foto dokumentasi tersebut terlihat bahwa Pemateri sedang menyampaikan materi sosialisasi. Untuk memudahkan para peserta memahami materi, maka Pemateri mencoba menyampaikan materi dengan menggunakan bahasa yang sederhana dan bahasa sehari-hari. Selain itu Pemateri juga memberikan ilustrasi melalui tayangan power point (PPT) yang kaya akan visual yang sangat mudah untuk difahami peserta. Hal tersebut bertujuan agar materi sosialisasi tersebut lebih melekat di ingatan para peserta. Setelah sosialisasi usai, para peserta pun mendapatkan salinan (copy) materi dalam bentuk power point (PPT) sehingga ini akan membantu peserta untuk dapat mengigat dan mengaplikasikan materi tersebut di rumah masing-masing.

Paparan yang disampaikan Pemateri benar-benar disimak dengan baik, selain itu juga pemateri pun mendapatkan cukup banyak pertanyaan dari peserta. Setelah penyampaian materi 
oleh pembicara, selanjutnya para peserta diberikan kesempatan untuk berdiskusi serta menyampaikan pendapat atau pertanyaan kepada pembicara terkait berbagai masalah dan kesulitan para ibu rumah tangga dalam mengawasi anak ketika menggunakan smartphone. Setelah diskusi dan tanya jawab selesai, kemudian para peserta dilatih untuk mensimulasikan bagaimana mendampingi anak ketika menggunakan smartphone. Hal ini sebagaimana pada gambar 4 berikut ini:

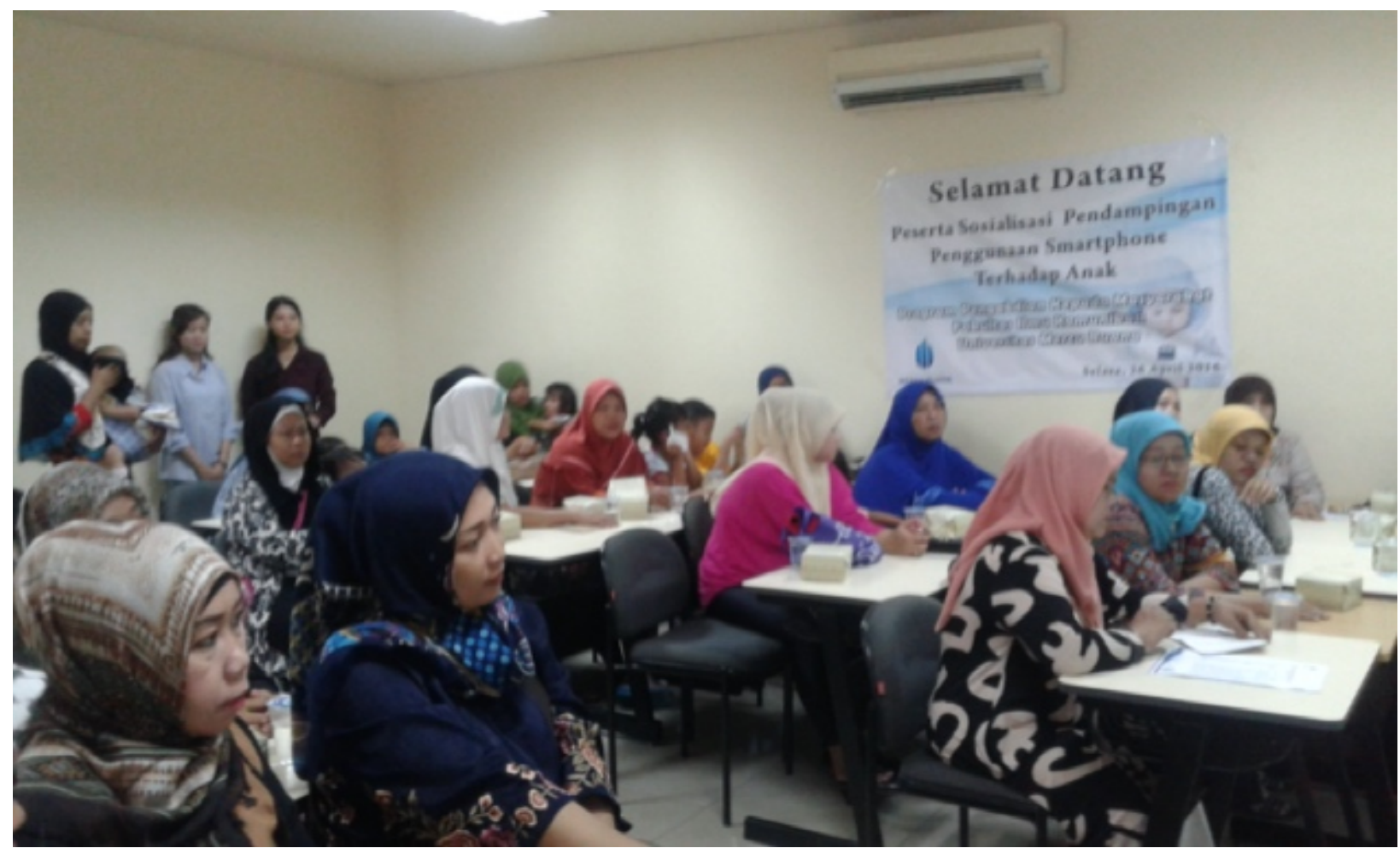

Gambar 4. Pemberian Materi Sosialisasi

Terlihat bahwa pada foto dokumentasi tersebut terlihat bahwa masyarakat sedang menyimak materi dengan seksama. Selain itu juga terlihat ada sebagian peserta sedang mencatat poin-poin penting materi dan sedang mempersiapkan pertanyaan untuk sesi diskusi. Dari visualisasi tersebut terlihat bahwa antusiasme masyarakat cukup tinggi, mengingat saat ini marak sekali anak yang kecanduan menggunakan smartphone secara berlebih, serta peserta menyadari bahwa masih kurangnya pengawasan mereka selaku orang tua pada aktivitas anak saat mengakses internet melalui smartphone masing-masing.

Pada sesi diskusi dan tanya jawab tersebut para peserta saling berinteraksi dan saling berlajar dan berbagai pengalaman satu sama lain. Selain itu juga Pemateri memberikan pemahaman bagaimana sebaiknya proses pendampingan pada anak saat menggunakan smartphone. Realitas ini telah jelaskan Zaden (1979) bahwa melalui sosialisasi maka setiap individu akan melakukan proses interaksi sosial yang mana seorang individu mulai mengenal cara berfikir, selanjutnya berperasaan dan bertingkah laku sehingga dia akan berperan dalam suatu lingkungan masyakat[6].

Penerapan sosialisasi dalam program pengabdian masyarakat ini yaitu bertujuan untuk memberikan pengetahuan yang berhubungan dengan nilai dan norma yang harus dipelajari terkait bagaimana orang tuan mengawasi anak dalam menggunakan smartphone. Hal ini senada dengan pendapat Riswandi [7] tujuan sosialisasi yaitu untuk mewariskan nilai dan norma kepada generasi 
penerus, serta membantu individu agar mampu mengenal serta beradaptasi dengan lingkungan sekitar. Selain itu sosialisasi juga merupakan upaya untuk memberikan pengetahuan terkait nilai dan norma yang ada dilingkungannya, sehingga individu akan mempu menjaga hubungan sosial dan menjadi bagian dari masyarakat, serta dapat mencegah terjadinya perilaku menyimpang yang akan dilakukan oleh seseorang.

Dengan demikian maka sosialiasi ini dapat mencegah terjadinya perilaku menyimpang yang akan dilakukan oleh anak yang belum memiliki kemampuan untuk menyaring informasi yang diperoleh melalui smartphone. Disinilah pentingnya sosialisasi ini agar masyarakat, khususnya para orang tua memiliki kesadaran dan pengetahuan terkait pentingnya pengawasan dan pendampingan terhadap anak dalam mengakses smartphone.

Tentu program pemdampingan penggunaan smartphone pada ini sangat relevan untuk dilakukan, mengingat penelitian yang dilakukan oleh Yen (2009), menemukan bahwa dari 10.191 remaja yang diteliti 30\% peserta mentoleransi penggunaan smartphone, $36 \%$ mengalami penarikan diri, 27\% kecanduan smartphone, 18\% sulit mengurangi penggunaan smartphone, dan 10\% mengalami gangguan interaksi sosial. Pemerintah mengakui bahwa smartphone dapat berisiko mengakibatkan kecanduan berlebihan. Sementara itu, fitur utama dari smartphone adalah operasi aplikasi berbasis internet. Dengan demikian, penggunaan smartphone harus diarahkan secara fungsional sehingga penggunaannya untuk kepentingan yang positif [8].

Remaja pengguna smartphone berlebihan akan memiliki dunianya sendiri, sehingga sering terlihat sibuk dengan smartphone bahkan mengabaikan orang disekitarnya. Dampak negative lainnya yaitu menjadikan pengguna jarang bersosialisasi dengan orang-orang disekitarnya. Kemudahan bersosialisasi dalam menggunakan smartphone, justru membuat terlihat anti sosial di kehidupan nyata. Sekelompok remaja mungkin saja berkumpul bersama, namun frekuensi interaksi rendah akibat fokus menggunakan smartphone masing-masing. Hal ini dapat memicu masalah pada interaksi sosial [8].

Secara teoritis, proses sosialisasi ini senada dengan pendapat Berger bahwa melalui proses sosialisasi ini maka anak akan didampingi oleh orang tua untuk dapat menjadi seorang anggota yang berpartisipasi dalam masyarakat [9]. Dalam konteks program sosialisasi ini, anak akan diajarkan norma-norma terkait hal-hal yang perlu dilakukan dan yang tidak perlu dilakukan pada saat mengakses smartphone. Secara umum sosialisasi dapat diartikan sebagai proses belajar individu untuk mengenal dan menghayati norma-norma serta nilai-nilai sosial sehingga terjadi pembentukan sikap untuk berprilaku sesuai dengan tuntutan dan perilaku masyarakatnya. Pengembangan diri seseorang tidak terlepas dari pengaruh interaksi dengan orang lain.

Menariknya pada sosialisasi tersebut peserta diajak untuk mensimulasikan bagaimana cara berkomunikasi yang baik, sehingga anak tidak merasa sedang diawasi tetapi merasa diperhatikan sebagai teman. Hal ini penting, mengingat hasil diskusi pada forum sosialisasi tersebut para peserta mengaku masih menggunakan bahasa-bahasa perintah dan kurang persuasif, hal ini berdampak pada perilaku anak yang mencuri-curi kesempatan untuk menggunakan smartphone tanpa orang tua mengetahui konten apa yang sedang diakses. Pada sosialisasi ini peserta benar-benar memahami bagaimana membangun komunikasi yang persuasif dengan anak, sehigga anak lebih mudah untuk didampingi tanpa merasa diawasi.

Melalui proses sosialisasi ini maka diharapkan anak pada saat menggunakan smartphone akan memiliki batasan, serta tidak terpisah dari pergaulan sosial masyarakat. Remaja tidak akan 
sibuk dengan smartphone, sampai mengabaikan orang disekitarnya, hal ini karena remaja atau anak memahami bagaimana menggunakan smartphone dengan bijak. Kemudahan bersosialisasi dalam menggunakan smartphone, justru membuat terlihat anti-sosial di kehidupan nyata, tentu hal ini sangat tidak benar sehigga sosialisasi ini akan memberikan pemahaman bahwa memperkuat pertemanan atau jaringan harus seimbang antara dunia maya dan dunia nyata.

Hasil sosialisasi ini diharapkan para peserta diharapkan memperoleh pengetahuan dan pemahaman terkait bagaimana dampak-dampak penggunaan smartphone, peserta diharapkan memperoleh pengetahuan dan pemahaman terkait informasi mengenai pentingnya mendampingi dan mengawasi anak dalam menggunakan smartphone, dan terakhir peserta diharapkan memperoleh pengetahuan dan pemahaman terkait bagaimana cara mendampingi dan mengawasi anak dalam menggunakan smartphone dengan tepat.

Melalui sosialiasi bijak menggunakan smartphone, anak akan memperoleh berbagai manfaat yaitu pertama, peningkatan ketajaman pengelihatan. Beberapa jenis game action disinyalir dapat merangsang pengelihatan anak menjadi lebih tajam. Kedua, merangsang anak untuk mengadaptasi teknologi terbaru. Ketiga, mendukung aspek akademis karena teknologi gadget dapat mendukung prestasi akademis anak. Seorang anak dapat melakukan browsing dengan gadget akan mudah untuk mencari informasi perihal pengetahuan yang ia dapat di sekolah. Jadi ia tidak perlu bersusah payah mencari katalog buku di perpustakaan untuk mencari informasi yang berkaitan dengan pengetahuan. Keempat, dapat meningkatkan kemampuan berbahasa. Hal ini dikarenakan dalam gadget dan game banyak menggunakan bahasa asing [10].

Berbagai bentuk kegiatan sosialisasi yang dapat memberikan pengetahuan kepada masyarakat harus terus dilakukan dan ditingkatkan. Hal ini dikarenakan bahwa universitas memiliki kewajiban moral dalam menjalankan tri dharma perguruan tinggi, yang salah satunya yaitu menyelenggarakan program pengabdian kepada masyarakat. Selain itu, program ini merupakan sarana bagi Perguruan Tinggi untuk dapat memberikan kontribusinya kepada masyarakat secara nyata. Untuk itu, temuan-temuan penelitian dapat dikomunikasikan kepada masyarakat dengan cara yang sederhana dan sesuai dengan permasalahan sehari-hari mereka, sehingga masyarakat dapat secara langsung merasakan manfaat dari penelitian-penelitian akademis.

\section{KESIMPULAN}

Dari rangkaian kegiatan Sosialisasi Pendampingan Penggunaan Smartphone Terhadap Anak ini dapat ditarik simpulan bahwa kegiatan sosialisasi ini sangat penting untuk dilakukan, mengingat masih banyaknya masyarakat, khsususnya Ibu rumah tangga yang kurang menyadari bahwa minimnya kontrol terhadap anak dalam penggunaan smartphone secara berlebihan sangatlah merugikan dan berbahaya. Hal ini terlihat dari hasil diskusi pada saat diskusi interaktif dalam kegiatan sosialisasi ini. Oleh karena itu, berbagai temuan dari hasil riset-riset akademik sangat diharapkan untuk dapat disampaikan kepada masyarakat, baik itu melalui pelatihan, seminar, sosialisasi dan lain sebagainya. Dengan demikian kajian-kajian ilmiah dapat diimplementasikan dalam mengedukasi masyarakat, sehingga berbagai dampak yang ditimbulkan teknologi informasi dapat diminimalisir dan justru masyarakat dapat memanfaatkan pada hal-hal yang lebih konstruktif. 


\section{DAFTAR PUSTAKA}

[1] F. Rahmandani, A. Tinus, and M. M. Ibrahim, "Analisis Dampak Penggunaan Gadget (Smartphone) Terhadap Kepribadian Dan Karakter (Kekar) Peserta Didik Di Sma Negeri 9 Malang," J. Civ. Huk., vol. 3, no. 1, p. 18, 2018.

[2] P. Haryani, "Sosialisasi E-Safety Parenting Sebagai Smart Solution dalam Pendampingan Penggunaan Gadget Pada Anak," J. ABDINUS J. Pengabdi. Nusant., vol. 3, no. 1, p. 83, 2019.

[3] P. A. Chusna, "Pengaruh Media Gadget Pada Perkembangan Karakter Anak," J. Din. Penelit., vol. 17, no. 2, pp. 315-330, 2017.

[4] M. Zaini and S. Soenarto, "Persepsi Orangtua Terhadap Hadirnya Era Teknologi Digital di Kalangan Anak Usia Dini,” J. Obs. J. Pendidik. Anak Usia Dini, vol. 3, no. 1, p. 254, 2019.

[5] A. Anwar, "Paradigma Sosialisasi Dan Kontribusinya Terhadap Pengembangan Jiwa Beragama Anak," Komunida Media Komun. Dan Dakwah, vol. 8, no. 2, pp. 155-167, 2018.

[6] D. Herdiana, "Sosialisasi Kebijakan Publik: Pengertian dan Konsep Dasar," J. Ilm. Wawasan Insa. Akad., vol. 1, no. 3, pp. 13-26, 2018.

[7] Riswandi, "Proposal Sosialisasi Pemilihan Umum 2014 pada Pemilih Pemula di Jakarta Barat," Jakarta, 2013.

[8] M. Muflih, H. Hamzah, and W. A. Puniawan, "PENGGUNAAN SMARTPHONE DAN INTERAKSI SOSIAL PADA REMAJA DI SMA NEGERI I KALASAN SLEMAN YOGYAKARTA Students' Use Of Smartphones and Social Interaction in SMAN I Kalasan Sleman Yogyakarta," Idea Nurs. J., vol. 1, no. 1, 2017.

[9] Haryanto and G. E. Nugrohadi, Pengantar Sosiologi Dasar. Jakarta: PT Prestasi Pustakaraya, 2011.

[10] M. G. Sobry, "Peran Smartphone Terhadap Pertumbuhan Dan Perkembangan Anak," J. Penelit. Guru Indones. - JPGI, vol. 2, no. 2, pp. 24-29, 2017. 